\title{
APPLICATION OF INDUCTIVE-DEDUCTIVE APPROACH TO IMPROVE THE ABILITY OF MATHEMATICAL COMMUNICATION AND SELF EFFICACY OF JUNIOR HIGH SCHOOL STUDENT
}

\author{
Bibih Hasibah $^{1}$, Euis Eti Rohaeti ${ }^{2}$, Bambang Aryan $^{3}$ \\ ${ }^{1}$ Pascasarjana IKIP Siliwangi Bandung, Jl. Jend. Sudirman \\ ${ }^{2}$ Program Studi Pendidikan Matematika IKIP Siliwangi Bandung, Jl. Jend. Sudirman \\ ${ }^{3}$ Program Studi Pendidikan Matematika IKIP Siliwangi Bandung, Jl. Jend. Sudirman \\ ${ }^{1}$ bibihhasibahsasor@gmail.com, ${ }^{2}$ e2rht@yahoo.com, ${ }^{3}$ bambang_aryan@yahoo.com
}

Received: March, 2018; Accepted: March, 2018

\begin{abstract}
This study aims to analyze the application of inductive-deductive approach to improve the ability of mathematical communication and se lf efficacy of junior high school students. The design of this study is quasi experiment. The research instruments used in this research are mathematical communication ability test and self efficacy attitude scale. The population in this study is all students of SMP Negeri 1 Soreang with this research sample is 80 students of class VIII as much as two classes chosen at random. Data analysis was done quantitatively to the data of mathematic communication ability and self efficacy attitude scale. In statistical calculations using SPSS 21, the results of the study show that improving students' mathematical communication skills whose learning uses a deductive-inductive approach is better than using ordinary learning. And self efficacy of junior high school students whose learning using inductive -deductive approach is better than using ordinary learning.
\end{abstract}

Keywords: Mathematical Communication Skills, Self Efficacy, Deductive-induktive approach

\begin{abstract}
Abstrak
Penelitian ini bertujuan untuk menganalisis penerapan pendekatan induktif-deduktif untuk meningkatkan kemampuan komunikasi matematik serta self efficacy siswa SMP. Desain penelitian ini adala kuasi eksperimen. Intrumen penelitian yang digunakan dalam penelitian ini berupa tes kemampuan komunikasi matematik dan skala sikap self efficacy. Populasi dalam penelitian ini adalah seluruh siswa SMP Negeri 1 Soreang dengan sampel penelitian ini adalah 80 siswa kelas VIII sebanyak dua kelas yang dipilih secara acak. Analisis data dilakukan secara kuantitatif yang dilakukan terhadap data kemampuan komunikasi matematik dan skala sikap self efficacy. Dalam perhitungan statistik menggunakan SPSS 21, hasil penelitian menunjukkan bahwa peningkatan kemampuan komunikasi matematik siswa yang pembelajarannya menggunakan pendekatan deduktif-induktif lebih baik daripada yang menggunakan pembelajaran biasa. Dan self efficacy siswa SMP yang pembelajarannya menggunakan pendekatan deduktif-induktif lebih baik daripada yang menggunakan pembelajaran biasa.
\end{abstract}

Kata Kunci: Kemampuan komunikasi matematik, self efficacy, pendekatan deduktif-induktif

How to Cite: Hasibah, B, Rohaeti, Euis E., \& Aryan, B. (2018). Application Of DeductiveInductive Approach To Improve The Ability Of Mathematical Communication And Self Efficacy Of Junior High School Student. JIML, 1 (1), 18-23.

\section{INTRODUCTION}

Mathematics is a universal language and hence the mathematical ability of learners in a country can be easily compared with other countries. Mathematics is also used as a measuring 
tool to determine educational progress in a country. From study studies or research both nationally and internationally, it can be seen that in general mathematical communication skills of our students are still low.

Low ability of learners in mathematical communication, and creative thinking can be observed in the process of daily learning. Often learners can not develop the understanding they have to think of new ideas and different ways of solving problems. Learners are also not confident to express what is in his mind as a way to find new solutions in menyelaesaikan math problems.

According (Anggareini \& Sumarmo, 2013) summarizes the opinions of some experts and NCTM and identifies some mathematical communication skills such as: a) Stating a situation, into drawings, diagrams, languages, symbols, expressions or mathematical models; b) State images, diagrams, languages, symbols, expressions or mathematical models into their own language; c) Listening, discussing, writing mathematics; d) Reading a mathematical presentation with understanding; e) Revisit a mathematical description in its own language; and 7) Compile questions about mathematics.

Through mathematical communication students exchange and explain their ideas or understanding to their friends. The communication process helps students construct the meaning of a series of mathematical processes and make generalizations. In an effort to explore and develop students' mathematical communication skills, teachers should expose students to a variety of contextual issues and invite them to communicate their respective ideas (Sumarmo \& Hidayat, 2013)

Then (Rahmi, Nadia, Hasibah, \& Hidayat, 2017) in the learning of hard skill mathematics and mathematical soft skills including values in cultural education and character that must be developed simultaneously and balanced through the learning of scientific approach. One of the mathematical soft skills is self efficacy. Self efficacy leads to one's belief in the ability to organize and carry out a series of actions in achieving the outcomes set.

To overcome the weakness of students above, the researcher chose an alternative approach of learning that is inductive-deductive approach. In learning mathematics, the inductive mindset is used by the teacher if in delivering learning materials starting from the things that are specific to the more general. Mathematics learning is primarily tied to SD / MI and SMP / Mts is still indispensable use of inductive mindset. This means that in the presentation of mathematics in both levels of education need to start from the special things, such as examples, gradually to a conclusion or a general nature. Conclusions can be either a definition or a theorem raised from those particular points (Soedjadi, 2000).

\section{METHOD}

This research method is quasi experiment, where writer take two class as sample of research. The first class gets an inductive-deductive approach and the second class gets regular learning. This research was conducted in SMP Negeri 1 Soreang. The development of students' self-efficacy variables on mathematics begins with the preparation of 36 grains of statements complete with 4 choices. The scale used is Likert scale. With choices of SS answers (strongly agree), S (agree), TS (disagree), and STS (strongly disagree). For calculation calculation using $\mathrm{SS}=4, \mathrm{~S}=3, \mathrm{TS}=2$, and $\mathrm{STS}=1$ for favorable (positive) statements, otherwise $\mathrm{SS}=1, \mathrm{~S}=2$, TS $=3$, and $\mathrm{STS}=4$ for unfavorable statements (negative). The instrument is then consulted with the supervisor to have content validity. Whereas in order to have empirical validity then the instrument is tested to know the validity, reliability of distinguishing power, and difficulty index. The mathematical test used is a test of mathematical creative thinking ability. 
The test of mathematical thinking ability is arranged in the form of a description. The reason for the preparation of the test in the form of a description because it is tailored to the purpose of this study which prioritizes the process rather than the results. The test in the form of a description does not give much chance to speculate, it may even encourage students to dare to express their opinions in their own way and language. The steps taken in the preparation of this instrument are (1) Making a grid of test questions based on indicators of communication ability matemati, (2) Creating scoring guidelines, (3) Preparing Test Problems; (4) Assess the suitability between the materials, indicators and test questions.

\section{RESULTS AND DISCUSSION}

\section{Results}

To see whether there is an improvement in the ability of mathematical communication skills whose learning using inductive -deductive approach with the learning using normal learning viewed from the level of initial ability of mathematics, then tested two a verages and two-lane anova test with $\alpha=0.05$ and the hypothesis is

Ho : $\mu_{1}=\mu_{2}$ (there is no difference in improving the ability of mathematical communication skills of junior high school students whose learning using inductive-deductive approach compared with ordinary learning)

$\mathrm{Ha}: \mu_{1}>\mu_{2}$ (Improving the ability of mathematical communication skills of junior high school students whose learning using inductive-deductive approach is better than learning using ordinary learning)

By criteria,

If sig $>0,05$ then $\mathrm{H} 0$ is accepted

If sig $\leq 0,05$ maka $\mathrm{H}_{0}$ is Rejected

Table 1. Two-Tiered Test

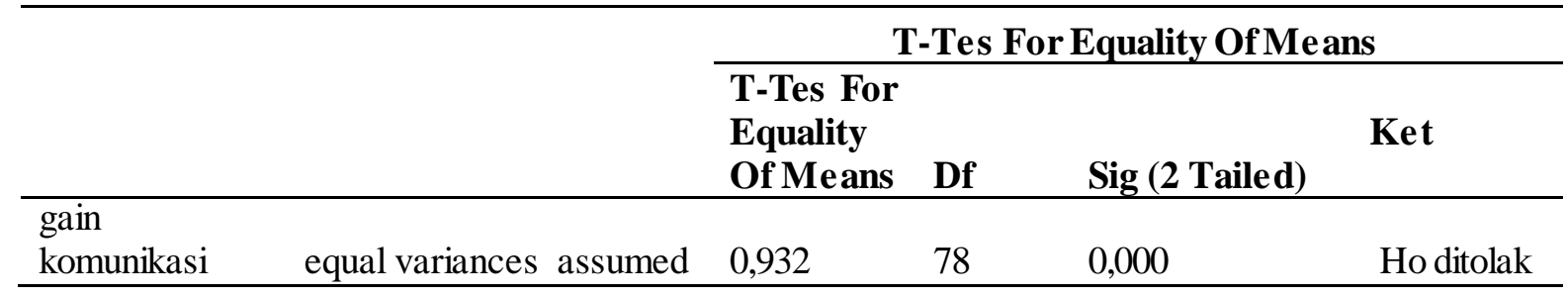

Based on the above table it can be seen that Sig. ( 2 tailed) is 0,000 so Sig. ( 1 tailed) to $\frac{0,000}{2}=$ 0.00 , the value meets the Sig criteria. (1 tailed) $\leq 0.05$ then Ho is rejected which means Improving students' mathematical communication skills ability of Junior High School whose learning using inductive-deductive approach is better than learning using ordinary learning. Then to see the average data gain mathematical communication ability from the level of ability of early mathematics seen by using 2 path Anova test, the following test criteria:

If Sig. > 0,05 then the mean of mathematical communication ability between TKAS (low, medium and high) is the same (there is no significant difference)

If Sig. $\leq 0,05$ then the average mathematical communication ability between TKAS (low, medium and high) is not the same (there are significant differences)

Table 2. Uji Anova 2 Jalur 


Dependent Variable: GAIN KOMUNIKASI
\begin{tabular}{|l|r|r|r|r|r|}
\hline Source & $\begin{array}{c}\text { Type III Sum of } \\
\text { Squares }\end{array}$ & df & Mean Square & \multicolumn{1}{c|}{ F } & Sig. \\
\hline Corrected Model & $1,053^{\mathrm{a}}$ & 5 &, 211 & 5,459 &, 000 \\
Intercept & 17,483 & 1 & 17,483 & 453,048 &, 000 \\
metode &, 857 & 1 &, 857 & 22,204 &, 000 \\
tkas &, 050 & 2 &, 025 &, 647 &, 527 \\
metode* tkas &, 059 & 2 &, 030 &, 771 &, 466 \\
Error & 2,856 & 74 &, 039 & & \\
Total & 22,912 & 80 & & & \\
Corrected Total & 3,909 & 79 & & & \\
\hline
\end{tabular}

a. R Squared $=, 269$ (Adjusted R Squared $=, 220$ )

Based on table 2 it is shown that Sig. is 0.527 . The value meets Sig criteria. $>0,05$ then the mean of mathematic communication ability between TKAS (low, medium and high) is the same (there is no significant difference).

Then to see whether the mathematical self efficacy of junior high school students whose learning using inductive-deductive approach is better than using ordinary learning in terms of initial mathematical ability level, it is seen from the test of two averages. With the hypothesis as follows:

Ho : $\mu_{1}=\mu_{2}$

(there is no difference in the level of self-efficacy between junior high school students whose learning uses inductive-deductive approaches compared with those using ordinary learning)

Ha $: \mu_{1}>\mu_{2}$

(the level of self-efficacy between junior high school students whose learning using the inductive-deductive approach is better than that using ordinary learning)

Tabel 3. Uji Dua Rerata

\begin{tabular}{ll} 
& $\begin{array}{l}\text { Self- } \\
\text { Efficacy }\end{array}$ \\
\hline Mann-Whitney U & 368,000 \\
\hline Wilcoxon W & 1184,000 \\
\hline Z & -4.160 \\
\hline Asymp.Sig. (2-tailed) & 0,000
\end{tabular}

Based on table 3 it appears that the sig ( 2 tailed) is 0,000 so that the sig ( 1 tailed) becomes $\frac{0,000}{2}=0,000$, the value meets sig $(1$ tailed $) \leq 0.05$ then Ho is rejected which means the level of self efficacy between junior high school students using a deductive-inductive approach is better than using ordinary learning.

Then to see the mean of self efficacy data from the level of ability of early mathematics seen by using 2 path Anova test, the following test criteria:

If Sig. $>0,05$ then the mean of self efficacy between TKAS (low, medium and high) is the same (there is no significant difference)

If Sig. $\leq 0,05$ then the mean of self efficacy between TKAS (low, medium and high) is not the same (there are significant differences) 
22 Hasibah, Rohaeti \& Aryan, Application Of Deductive-Inductive Approach To Improve The Ability Of Mathematical Communication And Self Efficacy Of Junior High School Student

Tabel 4. Anova Two Way Test

Tests of Between-Subjects Effects

Dependent Variable: SELF-EFFICACY

\begin{tabular}{|c|c|c|c|c|c|}
\hline Source & $\begin{array}{c}\text { Type III Sum of } \\
\text { Squares }\end{array}$ & df & Mean Square & $\mathrm{F}$ & Sig. \\
\hline Corrected Model & $7973,111^{a}$ & 5 & 1594,622 & 6,198 & ,000 \\
\hline Intercept & 645420,810 & 1 & 645420,810 & 2508,583 & ,000 \\
\hline metode & 6814,817 & 1 & 6814,817 & 26,487 & ,000 \\
\hline tkas & 984,492 & 2 & 492,246 & 1,913 & , 155 \\
\hline metode * tkas & 497,601 & 2 & 248,801 & ,967 & 385 \\
\hline Error & 19039,089 & 74 & 257,285 & & \\
\hline Total & 724150,000 & 80 & & & \\
\hline Corrected Total & 27012,200 & 79 & & & \\
\hline
\end{tabular}

a. R Squared $=, 295$ (Adjusted R Squared $=, 248$ )

Based on table 4 it is shown that Sig. is 0.155 . The value meets Sig criteria. $>0,05$ then the mean of self efficacy between TKAS (low, medium and high) is the same (there is no significant difference).

\section{Discussion}

Based on the results of data analysis for hypothesis testing, the conclusion from the findings obtained that the improvement of mathematical communication skills whose learning using the inductive-deductive approach is better than using ordinary learning in review of the initial ability level of the students. This is indicated by the significance value of anova test 2 lane 0.000 which means small lebig of $\alpha=0,05$ which means hence the mean of mathematic communication ability between TKAS (low, medium and high) is not equal (there is significant difference). Then for selff efficacy that the learning using deductive-inductive approach is better than those using ordinary learning in terms of the students' initial ability level of mathematics. This is indicated by the significance value of the anova test of 2 lanes 0.155 which means greater than 0.05 then the mean of self efficacy between TKAS (low, medium and high) is the same (no significant difference).

\section{CONCLUSION}

Based on the results of data analysis for hypothesis testing, the conclusion from the findings obtained that the improvement of mathematical communication skills whose learning using the inductive-deductive approach is better than using ordinary learning in review of the initial ability level of the students. And self-efficacy learning using a inductive-deductive approach is better than using ordinary learning in terms of the initial ability level of junior high school students.

\section{REFERENCES}

Anggareini, D., \& Sumarmo, U. (2013). Meningkatkan Kemampuan Pemahaman dan Komunikasi Matematik Siswa SMK melalui Pendekatan Kontekstial dan Strategi Formulate-Share-Listen-Create (FSLC). Jurnal Ilmiah Program Studi Matematika STKIP Siliwangi Bandung, 1 . 
Rahmi, S., Nadia, R., Hasibah, B., \& Hidayat, W. (2017). The Relation Between Self Efficacy Toward Math With The Math Communication Competence. Infinity Journal, 6, 177182.

Soedjadi. (2000). Educational Psychology: Theory and Parctice. Boston: Allyn \& Bacon.

Sumarmo, U., \& Hidayat, W. (2013). Kemampuan Komunikasi dan Berpikir Logis. Jurnal Matematika Dan Pendidikan Matematika, 1 . 